\title{
Temporal analysis and fungicide management strategies to control mango anthracnose epidemics in Guerrero, Mexico
}

\author{
Abraham Monteon Ojeda ${ }^{1}$, José Antonio Mora Aguilera ${ }^{1}$, Ángel Villegas Monter ${ }^{1}$, Cristian Nava Diaz ${ }^{1}$, \\ Elías Hernández Castro ${ }^{2}$, Gabriel Otero-Colina ${ }^{1}$ \& Javier Hernández Morales ${ }^{1}$
}

\begin{abstract}
${ }^{1}$ Instituto de Fitosanidad, Colegio de Postgraduados, km 35.5, Carr. México-Texcoco, Montecillo, Estado de México, C. Postal 56230, México; ${ }^{2}$ Universidad Autónoma de Guerrero, Javier Méndez Aponte 1 Fraccionamiento Servidor Agrario, Chilpancingo de Los Bravo, Guerrero, C. Postal 39070, México
\end{abstract}

Author for correspondence: Antonio Mora Aguilera, e-mail: aguilera@colpos.mx

\begin{abstract}
The temporal progress of anthracnose (Colletotrichum gloeosporioides) epidemics was studied in mango (Mangifera indica) orchards treated with fungicides from different chemical groups, mode of action, and application sequences in two regions of contrasting climates (sub-humid and dry tropics) in Guerrero, Mexico. Full flowering, initial setting, and 8-15mm $\varnothing$ fruits were identified as critical stages for infection. Epidemics started 20-26 days after swollen buds, and maximum severity was attained at 40-42 days after the first symptoms were detected. The Weibull model described $\left(r^{2} \geq 0.89\right)$ anthracnose epidemics in both floral and vegetative flushes. Active ingredients of different fungicide groups, mode of action, and residuality such as myclobutanil, azoxystrobin, cyprodinil+fludioxonil, quinoxyfen, and chlorotalonil + sulfur led to significantly low values ( $\mathrm{LSD} \leq 0.05 \%)$ in the $\mathrm{Y}_{\mathrm{f}}, \mathrm{AUDPC}$ and $\mathrm{b}^{-1}$ parameters. The best strategy was to initiate a preventive treatment with a systemic ingredient, independently of its chemical group. Severity of the disease in floral ( $\mathrm{Fl}$ ) and vegetative flushing (Veg) in the sub-humid tropic was related with temperature $\geq 30^{\circ} \mathrm{C}\left(\mathrm{r}_{\mathrm{Fl}}=0.79-0.86 ; \mathrm{r}_{\mathrm{Veg}}=0.80-0.95\right)$ and relative humidity $\geq 90 \%\left(\mathrm{r}_{\mathrm{F} 1}=0.66-0.86 ; \mathrm{r}_{\mathrm{Veg}}=0.67-0.94\right)$. In both regions, conidial sporulation was related to temperature $\geq 30^{\circ} \mathrm{C}(\mathrm{r}=0.72-0.74)$, relative humidity $<60 \%(\mathrm{r}=0.66)$, severity $\left(\mathrm{r}_{\mathrm{Fl}}=0.62-0.98 ; \mathrm{r}_{\mathrm{Veg}}=0.75-0.97\right)$ and dew point $\leq 25^{\circ} \mathrm{C}(\mathrm{r}=0.68-0.69)$.

Key words: Colletotrichum gloeosporioides, Mangifera indica, epidemics, fungicides.
\end{abstract}

\section{INTRODUCTION}

Mango (Mangifera indica L.) crops, originally from India, are grown in most tropical and sub-tropical zones in the world (Galan, 1999), where they represent the third most important tropical fruit group after banana (Musa spp.) and orange (Citrus sinensis L.) (FAOSTAT, 2010). The main producers are India, China, Thailand, Pakistan, Mexico, Indonesia and Brazil (FAOSTAT, 2010). In Mexico, mango was grown in 183,108 ha with a total production of $1,632,649$ ton and a value of $\$ 312$ million dollars in 2010 . States of Guerrero, Nayarit, Sinaloa, Chiapas, Oaxaca, Michoacan, and Veracruz produce over $90 \%$ of the national volume. Guerrero is the main producer, and the principal crop regions in this State are Costa Grande (sub-humid tropic), Tierra Caliente (dry tropic) and Costa Chica (SIAP, 2010).

Anthracnose (Colletotrichum gloeosporioides Penz.) is the most important disease of the crop in all mango production areas in the world (Arauz, 2000; Mora et al., 2002). It is more severe with high relative humidity and abundant rainfall and the symptoms can be observed on leaves, flowers, fruits, and branches of all ages. The disease can cause losses varying from $50 \%$ to $100 \%$ in unmanaged orchards under a favorable environment (Arauz, 2000; Benitez et al., 2003; Mora et al., 2002). Symptom in the foliage consist of dark angular spots, 3-5 mm long, which can coalesce and necrose more extended areas generally surrounded by a yellow chlorotic halo. In the inflorescence it appears as tiny black spots, which cause extensive necrosis (blight) of flowers and small fruit fall off easily because of wind or rain leaving only the rachis attached to the tree. Affected fruits in early development can remain mummified in necrotic panicles or be aborted altogether. In the case of fruits nearing maturity the infections are quiescent and cause irregular dark spots that quickly rot the pulp of the fruit when it reaches senescence. In young vegetative stems, it causes canker lesions (Jeffries et al., 1990; Holguín et al., 2009).

Colletotrichum gloeosporioides produces conidia and ascospores in acervula and perithecia in leaves, inflorescences and aborted or mummified fruits, which are spread mainly through rain water splashing or the wind. Germination, production of germinating tubes and appressoria optimum at 25 and $30^{\circ} \mathrm{C}$ and 90 to $100 \%$ relative humidity (Jeffries et al., 1990). The infected organs constitute a reservoir of propagules for later infections (Estrada et al., 2000; Sangeetha \& Rawal, 2009). 
Epidemiological studies of anthracnose are scarce in Mexico. In Iguala, Guerrero, severity of anthracnose was influenced by conidial density and rainfall, and showed monomolecular and Gompertz temporal progress curves (Acosta, 2002). In Michoacan, epidemics of anthracnose in flowering stage were adequately described by the Weibull model $\left(\mathrm{r}^{2} \geq 0.93\right)$, and conidial density was positively related with the severity ( $r=0.74)$ (Guillen, 2000).

In Mexico, management of anthracnose has been mainly based on the use of benzimidazole fungicides (Vega, 1994). However, resistance to benzimidazole in C. gloeosporioides isolates has been previously reported (Hsin et al., 2009; Gutierrez et al., 2003). Contrastingly, triazole, imidazole, estrobilurine, and multi-sites protecting compounds have shown satisfactory control and low risk of resistance (Frac, 2006; Gutierrez et al., 2003; Nieto et al., 2003; Sundravadana et al., 2009).

The high aggressiveness of the pathogen, as well as the presence of susceptible tissue in different vegetative or floral flushing in the same growing season limits the rotation of active ingredients with a low risk of resistance. The intensity of epidemics depends on the susceptibility of varieties, the number and intensity of grow flushing and weather, among other relevant factors, and it is indispensable generate studies to improve control efficiency by zones of economic importance of the crop. Thus, the objectives of the present work were to 1) study the temporal progress of anthracnose epidemics under the influence of an alternation of fungicides from different groups, mode of action and application sequence; and 2) determine the relationship between meteorological factors and pathogen and disease intensity variables in two regions with contrasting climates (sub-humid and dry tropics) in Guerrero, Mexico.

\section{MATERIALS AND METHODS}

\section{Study area}

The study was carried out during the 2010-2011 productive cycle in two orchards: 1) Commercial orchard "Las Tunas" with Manila cv. trees, 14-15 years old established in a grid pattern $10 \times 10 \mathrm{~m}$, located in Tecpan

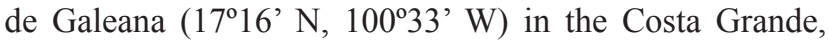
Guerrero, Mexico, altitude $20 \mathrm{~m}$. Mean annual rainfall and temperature are $1199 \mathrm{~mm}$ and $27^{\circ} \mathrm{C}$ (sub-humid tropics) and the soil is reddish sandy loam (SMN, 1971-2012). 2) Commercial orchard "Zozontla 1" with Haden cv. trees, 3040 years old planted in staggered rows $10 \times 10 \mathrm{~m}$ located in Arcelia $\left(18^{\circ} 18.9^{\prime} \mathrm{N}, 100^{\circ} 18.6^{\prime} \mathrm{W}\right)$ in the Tierra Caliente region (dry tropic), Guerrero, Mexico, at an altitude of 320 $\mathrm{m}$. Mean annual rainfall and temperature are $1158 \mathrm{~mm}$ and $27.7^{\circ} \mathrm{C}$ and the soil is dark brown sandy loam (SMN, 19712012).

In the orchards, the agronomic management consisted of: a) sanitary pruning; b) major and foliar chemical fertilization according to soil and plant analysis, and weekly watering; d) collection and elimination of harvest residues or infected fruits from the ground (inoculum); e) flowering induction $\left(\mathrm{KNO}_{3}, 3 \%\right)$. Additionally, five experimental treatments were applied for chemical control of anthracnose based on the rotation of active ingredients from different chemical groups and modes of action (Table 1). Fungicide management strategies was based on the floral phenology model proposed by Guillen (2000), who considered from swollen buds until fruit with a diameter of $8 \mathrm{~mm}$. However, in this study the record was extended to fruits diameter of $\approx 15 \mathrm{~mm}$. The systemic ingredients were applied every 15 days, and the contact ingredients were applied every eight days. Sprayings were made with a Swissmex ${ }^{\circledR}$ agricultural handbarrow with a capacity of $500 \mathrm{~L}$ and flow of $34.2 \mathrm{~L} / \mathrm{min}$ at $20 \mathrm{bar}$, motor $5.5 \mathrm{HP}(4.1 \mathrm{kw})$ at $3,600 \mathrm{rpm}$, two $50 \mathrm{~m}$ hoses with aspersion handles. The fungicides were applied in commercial doses: azoxystrobin $0.25 \mathrm{~g} / \mathrm{L}$, myclobutanil $0.08 \mathrm{~g} / \mathrm{L}$, cyprodynil+fludioxonil $0.075 \mathrm{~g} / \mathrm{L}$, quinoxyfen $0.05 \mathrm{~mL} / \mathrm{L}$, copper oxychloride $2.5 \mathrm{~g} / \mathrm{L}$, mancozeb $0.8 \mathrm{~g} / \mathrm{L}$, captan $1.25 \mathrm{~g} / \mathrm{L}$, chlorotalonil $2.88 \mathrm{~g} / \mathrm{L}$ and elemental sulfur $1.35 \mathrm{~mL} / \mathrm{L}$.

\section{Experimental design and disease severity assessment}

Trees with similar trunk diameter and foliage volume were selected. Five chemical control treatments were evaluated in three growth flushing (vegetative and floral) in Tecpan de Galeana and one in Arcelia, Guerrero. A randomized block design with four replicates was used, in it each tree was the experimental unit. To evaluate the severity of each floral rhythm, classes 5 and 7 logarithm scales were used (Table 2), as proposed by Guillen (2000). These classes considered the ratio of affected foliar area (where $0=$ healthy tissue and $5=>5 \%$ damaged area), as well as flowers and fruits with necroses (where $0=$ healthy tissue and $7=>97 \%$ necrotic panicles). Five inflorescences and five vegetative shoots were randomly tagged in each experimental tree on each date because of the lack effect of orientation (Guillen, 2000). Severity evaluations were done weekly from the detection of swollen buds until the fruits reached 8-15 $\mathrm{mm} \varnothing$ with the formula.

$$
S=\frac{\sum_{i=1}^{k} X_{k i} * N_{k i}}{N_{i}}
$$

In which $\mathrm{S}=$ severity at time $\mathrm{i}, \mathrm{X}_{\mathrm{ki}}=$ damage level $\mathrm{k}$ at time $\mathrm{i}, \mathrm{N}_{\mathrm{ki}}=\#$ inflorescences with damage level $\mathrm{k}$ at time $\mathrm{i}, \mathrm{N}_{\mathrm{i}}=\#$ inflorescences evaluated at time $\mathrm{i}$.

\section{Temporal analysis and effect of treatments}

The disease progress curves were described by the Weibull model (Pennypecker et al., 1980), the area under disease progress curve (AUDPC) (Campbell \& Madden, 1990), variance analyses and mean separation of final severity $\left(\mathrm{y}_{\mathrm{f}}\right)$, ratio $\left(\mathrm{b}^{-1}\right)$ and AUDPC were done using the LSD model with a reliability of $95 \%$ with $\mathrm{SAS}^{\circledR}$ software v.9.1.3 (SAS Institute Inc, 2003). 
TABLE 1 - Treatments applied per floral flushing in mango orchards in each region (sub-humid and dry tropics) of Guerrero México

\begin{tabular}{|c|c|c|}
\hline Treatments & $\begin{array}{l}\text { Tecpan de Galeana } \\
\text { (sub-humid tropic) }\end{array}$ & $\begin{array}{c}\text { Arcelia } \\
\text { (dry tropic) }\end{array}$ \\
\hline & Floral flushing I (induced) & Floral flushing I (natural) \\
\hline tla & $\mathrm{C}^{1}+\mathrm{S}^{1 \mathrm{a}}+\mathrm{C}^{1}+\mathrm{S}^{2 \mathrm{a}}$ & $\mathrm{C}^{1}+\mathrm{S}^{1 \mathrm{a}}+\mathrm{C}^{1}+\mathrm{S}^{2 \mathrm{a}}$ \\
\hline $\mathrm{t} 2 \mathrm{a}$ & $\mathrm{S}^{1 \mathrm{a}}+\mathrm{C}^{1}+\mathrm{S}^{2 \mathrm{a}}+\mathrm{C}^{1}$ & $\mathrm{~S}^{1 \mathrm{a}}+\mathrm{C}^{1}+\mathrm{S}^{2 \mathrm{a}}+\mathrm{C}^{1}$ \\
\hline $\mathrm{t} 3 \mathrm{a}$ & $\mathrm{S}^{1 \mathrm{a}}+\mathrm{C}^{1}+\mathrm{C}^{2 \mathrm{a}}+\mathrm{S}^{1}$ & $\mathrm{~S}^{1 \mathrm{a}}+\mathrm{C}^{1}+\mathrm{C}^{2 \mathrm{a}}+\mathrm{S}^{1}$ \\
\hline $\mathrm{t} 4 \mathrm{a}$ & $\mathrm{C}^{1}+\mathrm{S}^{1 \mathrm{a}}+\mathrm{S}^{2 \mathrm{a}}+\mathrm{C}^{1}$ & $\mathrm{C}^{1}+\mathrm{S}^{1 \mathrm{a}}+\mathrm{S}^{2 \mathrm{a}}+\mathrm{C}^{1}$ \\
\hline \multirow[t]{2}{*}{ t5a } & Check & Check \\
\hline & $\begin{array}{l}\mathrm{S}^{1 \mathrm{a}}=\text { myclobutanil, } \mathrm{C}^{1}=\text { copper oxychloride }+ \\
\text { sulfur, } \mathrm{S}^{2 \mathrm{a}}=\text { azoxystrobin, } \mathrm{C}^{2}=\text { clorotalonil }+ \text { sulfur }\end{array}$ & $\begin{array}{l}\mathrm{S}^{1 \mathrm{a}}=\text { myclobutanil, } \mathrm{C}^{1}=\text { copper oxychloride }+ \text { sulfur, } \\
\mathrm{S}^{2 \mathrm{a}}=\text { azoxystrobin, } \mathrm{C}^{2}=\text { clorotalonil }+ \text { sulfur }\end{array}$ \\
\hline & Floral flushing II (induced) & \\
\hline $\mathrm{t} 1 \mathrm{~b}$ & $\mathrm{Cu}+\mathrm{S}$ & \\
\hline $\mathrm{t} 2 \mathrm{~b}$ & $\mathrm{Clo}+\mathrm{S}$ & \\
\hline $\mathrm{t} 3 \mathrm{~b}$ & $\mathrm{Ma}+\mathrm{S}$ & \\
\hline $\mathrm{t} 4 \mathrm{~b}$ & $\mathrm{Ca}+\mathrm{S}$ & \\
\hline \multirow[t]{2}{*}{$\mathrm{t} 5 \mathrm{~b}$} & Check & \\
\hline & $\begin{array}{l}\mathrm{Cu}+\mathrm{S}=\text { copper oxychloride }+ \text { sulfur, } \\
\mathrm{Clo}+\mathrm{S}=\text { chlorotalonil }+ \text { sulfur, } \mathrm{Ma}+\mathrm{S}=\text { mancozeb }+ \\
\text { sulfur, } \mathrm{Ca}+\mathrm{S}=\text { captan }+ \text { sulfur }\end{array}$ & \\
\hline & Floral flushing III (natural) & \\
\hline $\mathrm{t} 1 \mathrm{c}$ & $\mathrm{C}^{2}+\mathrm{S}^{1 \mathrm{c}}+\mathrm{C}^{2}+\mathrm{S}^{2 \mathrm{c}}$ & \\
\hline $\mathrm{t} 2 \mathrm{c}$ & $\mathrm{S}^{1}+\mathrm{C}^{2 \mathrm{c}}+\mathrm{S}^{2}+\mathrm{C}^{2 \mathrm{c}}$ & \\
\hline $\mathrm{t} 3 \mathrm{c}$ & $\mathrm{S}^{1}+\mathrm{C}^{2 \mathrm{c}}+\mathrm{C}^{2}+\mathrm{S}^{2 \mathrm{c}}$ & \\
\hline $\mathrm{t} 4 \mathrm{c}$ & $\mathrm{C}^{2}+\mathrm{S}^{1 \mathrm{c}}+\mathrm{S}^{2 \mathrm{c}}+\mathrm{C}^{2}$ & \\
\hline $\mathrm{t} 5 \mathrm{c}$ & Check & \\
\hline & $\begin{array}{l}\mathrm{C}^{2}=\text { chlorotalonil + sulfur, } \mathrm{S}^{1 \mathrm{c}}= \\
\text { (cyprodinil+fludioxonil), } \mathrm{S}^{2 \mathrm{c}}=\text { quinoxyfen }\end{array}$ & \\
\hline
\end{tabular}

TABLE 2 - Logarithmic scale for evaluation of anthracnose (C. gloeosporioides) (Guillén, 2000) during three floral flushes in mango (Mangifera indica) commercial orchards "Las Tunas" Tecpan de Galeana, Guerrero. cv. Manila and "Zozontla 1", Arcelia, Guerrero. cv. Haden. Productive cycle 2010-2011

\begin{tabular}{|c|c|c|}
\hline \multirow[t]{3}{*}{ Classes } & \multicolumn{2}{|c|}{ Range on each tissue type } \\
\hline & Leaf & Inflorescence \\
\hline & ${ }^{\mathrm{z}}$ Severity (\% of Leaf area affected) & ${ }^{\mathrm{z}}$ Severity (\% of tissue affected) \\
\hline 0 & 0 & 0 \\
\hline 1 & $>0-1.20$ & $>0-3$ \\
\hline 2 & $>1.2-1.94$ & $>3-11$ \\
\hline 3 & $>1.94-3.13$ & $>11-33$ \\
\hline 4 & $>3.13-5.0$ & $>33-67$ \\
\hline 5 & $>5.0$ & $>67-89$ \\
\hline 6 & & $>89-97$ \\
\hline 7 & & $>97-100$ \\
\hline
\end{tabular}

\section{Meteorological information}

Temperature $\left({ }^{\circ} \mathrm{C}\right)$, rainfall $(\mathrm{mm})$, relative humidity $(\mathrm{RH} \%)$, dew point $\left({ }^{\circ} \mathrm{C}\right)$, and wind speed and direction $(\mathrm{km} / \mathrm{h})$ were recorded every two hours with a Vantage Pro2 Weather Station ${ }^{\circledR}$ (Davis Instruments ${ }^{\circledR}$ Hayward CA) computerized meteorological station equipped with the Wheatherlink ${ }^{\circledR}$ software for Windows ${ }^{\circledR}$, v.7.1.

\section{Seasonal conidia sampling}

To estimate the conidial density of $C$. gloeosporioides in the air, a volumetric trap created by the Interdisciplinary Mango Research Group was used (Mora et al., 2003). The trap was placed $1.5 \mathrm{~m}$ above the ground level. Air suction was done with an industrial fan motor with a plastic frame of $8 \times 8 \mathrm{~cm}$, at $12 \mathrm{v}$ with a volumetric capacity of $2.3-3.5 \mathrm{~L}$ 
air/min. Within the trap, the conidia impacted against an adhesive tape placed around a gyrating mechanical drum with a seven day periodicity. Every tape, $3.5 \times 30.3 \mathrm{~cm}$, was sectioned from transparent self-adhesive polypropylene rolls $\left(\right.$ Contac $\left.^{\circledR}\right)$ and placed on its non-adhesive side on a hygrothermograph sheet (weekly trapping set) to differentiate individual sampling days, and fitted around the drum. The tapes were removed weekly, and examined with a compound microscope at $40 \mathrm{x}$ (Master Olympus ${ }^{\circledR}$ ) for daily and weekly quantification of conidia.

\section{Correlation analysis}

The Pearson correlation coefficient ( $\mathrm{r}$ ) was calculated between severity or conidial density of $C$. gloeosporioides in the air and the weather related variables: temperature, relative humidity, rainfall, dew point, and wind speed and direction using the following intervals (hours/weeks): temperature $\left(<20,20-26.9,27-29.9,30-34.9\right.$ and $\left.\geq 35^{\circ} \mathrm{C}\right)$, relative humidity $(<60 \%, 60-89.9 \%$ and $\geq 90 \%)$, dew point $\left(<15,15-19.9,20-24.9\right.$ and $\left.\geq 25^{\circ} \mathrm{C}\right)$, mean wind speed $(<1.0$, $1-1.9$ and $\geq 2 \mathrm{~km} / \mathrm{h}$ ) and direction.

\section{RESULTS}

\section{Disease evaluation and temporal analysis}

The severity scales (Table 2) allowed to estimate the temporal development of anthracnose epidemic and confirmed full flowering, initial set $(3-5 \mathrm{~mm} \varnothing$ fruit) and $8-15 \mathrm{~mm}$ diameter fruit as the critical phenological stages for infection. In Tecpan de Galeana (sub-humid tropic), the first symptoms were visually detected at 23 days after swelling of buds (full flowering) and defined the beginning of epidemics, given the significant availability of susceptible tissue. Maximum severity varied between classes 3-6 (11$97 \%$ ) in inflorescence (Fl) and 2-4 (1.2-5.0\%) in vegetative shoots (Veg), and was reached between 42 and 50 days after onset of symptoms. In Arcelia (tropical dry) the first symptoms manifested 26 days after full flowering. Maximum severity varied between classes 4-5 (inflorescence) and 2-4 (vegetative) and was reached 40 days after the onset of symptoms. For both tissues (floral and vegetative shoots) and locations, the highest severity in inflorescence (89-97\%) and vegetative shoots $(>5 \%)$ were observed in the check treatment (without fungicides) (Figures 1 and 2, Table 2). The Weibull model well described floral and vegetative epidemics in Tecpan de Galeana $\left(\mathrm{r}_{\mathrm{Fl}}=0.95-0.99 ; \mathrm{r}_{\mathrm{Veg}}=0.90-0.98\right)$ and Arcelia $\left(\mathrm{r}_{\mathrm{Fl}}=0.89 ; \mathrm{r}_{\mathrm{Veg}}=0.92\right)$ with a reliability of $95 \%$ (Tables 3 and 4$)$.

\section{Effect of treatments}

In Tecpan de Galeana, three mixed growth flushings (floral and vegetative) were present, while there was only one in Arcelia. The effectiveness of the experimental chemical treatments was similar in both phenology stages (floral shoots and vegetative). Treatments $3 \mathrm{a}$ and $3 \mathrm{c}\left(\mathrm{S}^{\mathrm{a}}+\mathrm{C}^{1}+\mathrm{C}^{1}+\right.$ $\mathrm{S}^{2 \mathrm{a}} ; \mathrm{S}^{1 \mathrm{c}+}+\mathrm{C}^{2}+\mathrm{C}^{2}+\mathrm{S}^{2 \mathrm{c}}$ ), where; $\mathrm{S}^{1 \mathrm{a}}=$ myclobutanil, $\mathrm{C}^{1}=$ copper oxychloride + sulfur, $\mathrm{S}^{2 \mathrm{a}}=$ azoxystrobin, $\mathrm{C}^{2}=$ clorotalonil

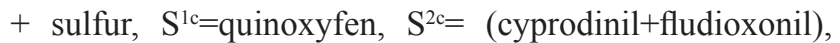
showed the lowest values for $\mathrm{Y}_{\mathrm{f}}$, AUDPC and $\mathrm{b}^{-1}$ (Tables 3 and 4) in flushing one and three and were the most consistent in both regions. However, when it was necessary to apply only contact ingredients on the second growth flushing to reduce the risk of resistance from excessive use of systemic chemicals, treatment $2 \mathrm{~b}(\mathrm{Clo}+\mathrm{S})$, where $\mathrm{Clo}=$ Chlorotalonil, $\mathrm{S}=$ sulfur, showed the lowest values in $\mathrm{Y}_{\mathrm{f}}, \mathrm{AUDPC}$, and $\mathrm{b}^{-1}$ on flushing tow (Tables 3 and 4).

\section{Correlation analysis}

In Tecpan de Galeana, the severity of the disease in inflorescence and vegetative shoots increased for temperatures $\geq 30^{\circ} \mathrm{C} \quad\left(\mathrm{r}_{\mathrm{FI}}=0.79-0.88 \quad\right.$ y $\left.\quad \mathrm{r}_{\mathrm{Veg}}=0.80-0.95\right)$; relative humidity $\geq 90 \%\left(\mathrm{r}_{\mathrm{FI}}=0.66-0.86 ; \mathrm{r}_{\mathrm{Veg}}=0.67-0.94\right)$ and conidial density of $C$. gloeosporioides in the air $\left(\mathrm{r}_{\mathrm{FI}}=0.62-\right.$ $\left.0.87 ; \mathrm{r}_{\mathrm{Veg}}=0.75-0.95\right)$. On the other hand, the seasonal density of conidia in the air was significantly correlated with temperature $\geq 30^{\circ} \mathrm{C}(\mathrm{r}=0.72)$, relative humidity $<60 \%$ $(\mathrm{r}=0.66)$, dew point $<15^{\circ} \mathrm{C}(\mathrm{r}=0.68)$ and wind $<1 \mathrm{~km} / \mathrm{h}$ $(\mathrm{r}=0.55)$ with west direction $\left(270^{\circ}\right)(\mathrm{r}=0.58)$ (Figure 3$)$. In Arcelia, severity in floral and vegetative tissue was associated with the density of conidia in the air $\left(\mathrm{r}_{\mathrm{Fl}}=0.96 \mathrm{y}\right.$ $\mathrm{r}_{\mathrm{Veg}}=0.97$ ), and this factor was associated with temperature $\geq 35^{\circ} \mathrm{C}(\mathrm{r}=0.74)$, relative humidity $\leq 60 \%(\mathrm{r}=0.66)$, dew point $20-24.9^{\circ} \mathrm{C}(\mathrm{r}=0.69)$ and wind $1-1.9 \mathrm{~km} / \mathrm{h}(\mathrm{r}=0.71)$ with SW direction (0.70) (Figure 4).

\section{DISCUSSION}

The scales were effective and facilitated the evaluation as reported by Guillen (2000) and allowed to discriminate the control effectiveness among fungicides. Conditions of temperature and humidity necessary for the development of anthracnose prevailed in Tecpan de Galeana $\left(\geq 30^{\circ} \mathrm{C}\right.$ and $\left.\geq 90 \%\right)$ and Arcelia $\left(\geq 35^{\circ} \mathrm{C}\right.$ and $<60 \%$ ) during the winter 2010 - spring 2011 period (Estrada et al., 2000). Even when vegetative epidemics do not directly affect flowers or fruits in formation, they are very important as a source of inoculum for inflorescences in mixed budding (floral and vegetative) or fruits in early or late formation, besides contributing to increasing the inoculum in the same or following cycles, and thus its epidemic importance must be established and included in regular control programs.

Mango usually flowers between December and February in tropical and sub-tropical regions of the northern hemisphere (Osuna et al., 2000). However, the periodic presence of cold winds from the Pacific and the Gulf of Mexico in coastal zones significantly modify the plants' phenology given that there is a positive relationship between temperature decreasing below $20^{\circ} \mathrm{C}$ and floral initiation and differentiation processes (Osuna et al., 2000). Additionally, the higher humidity of marine winds favors a most number of 


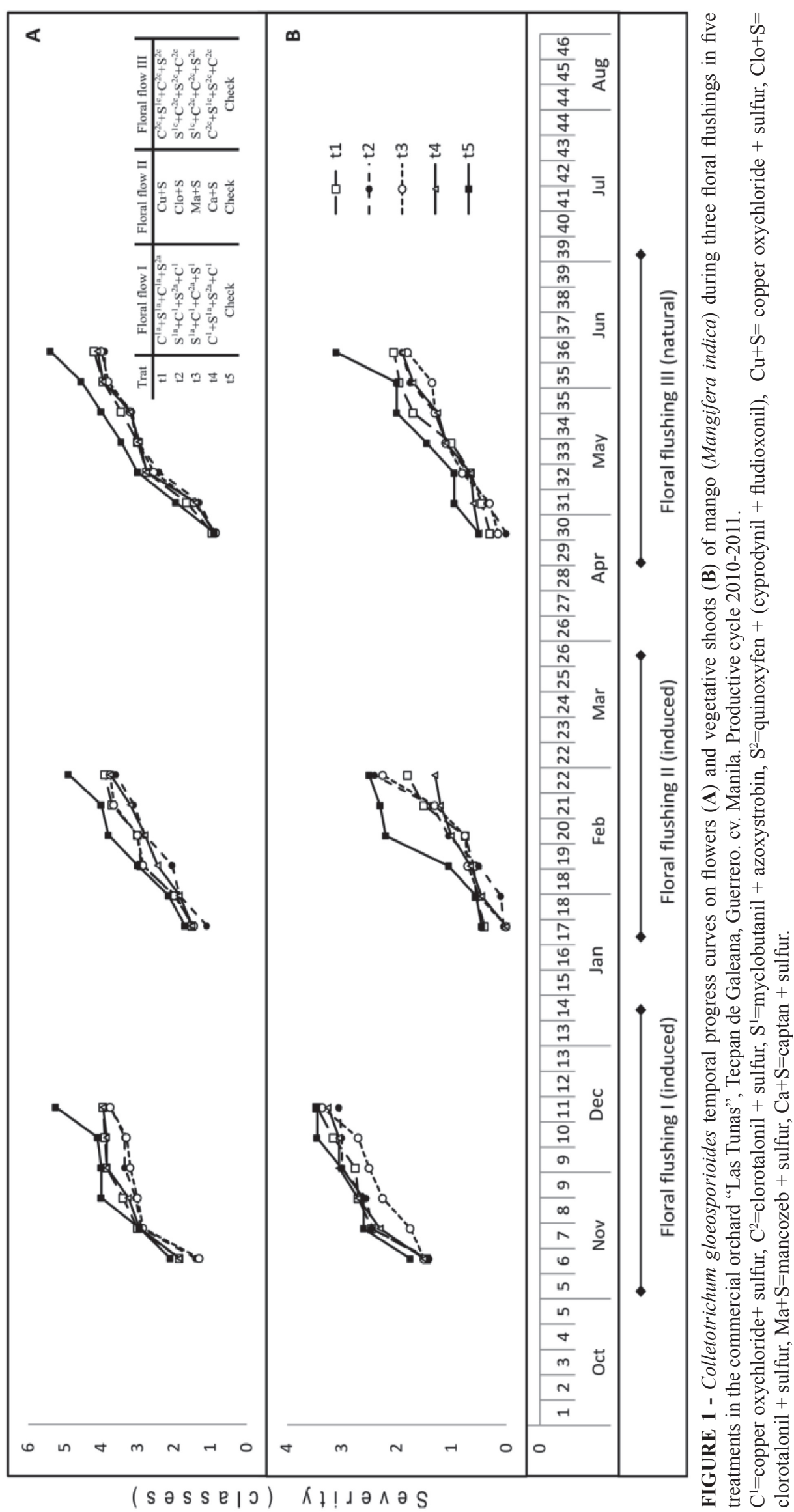




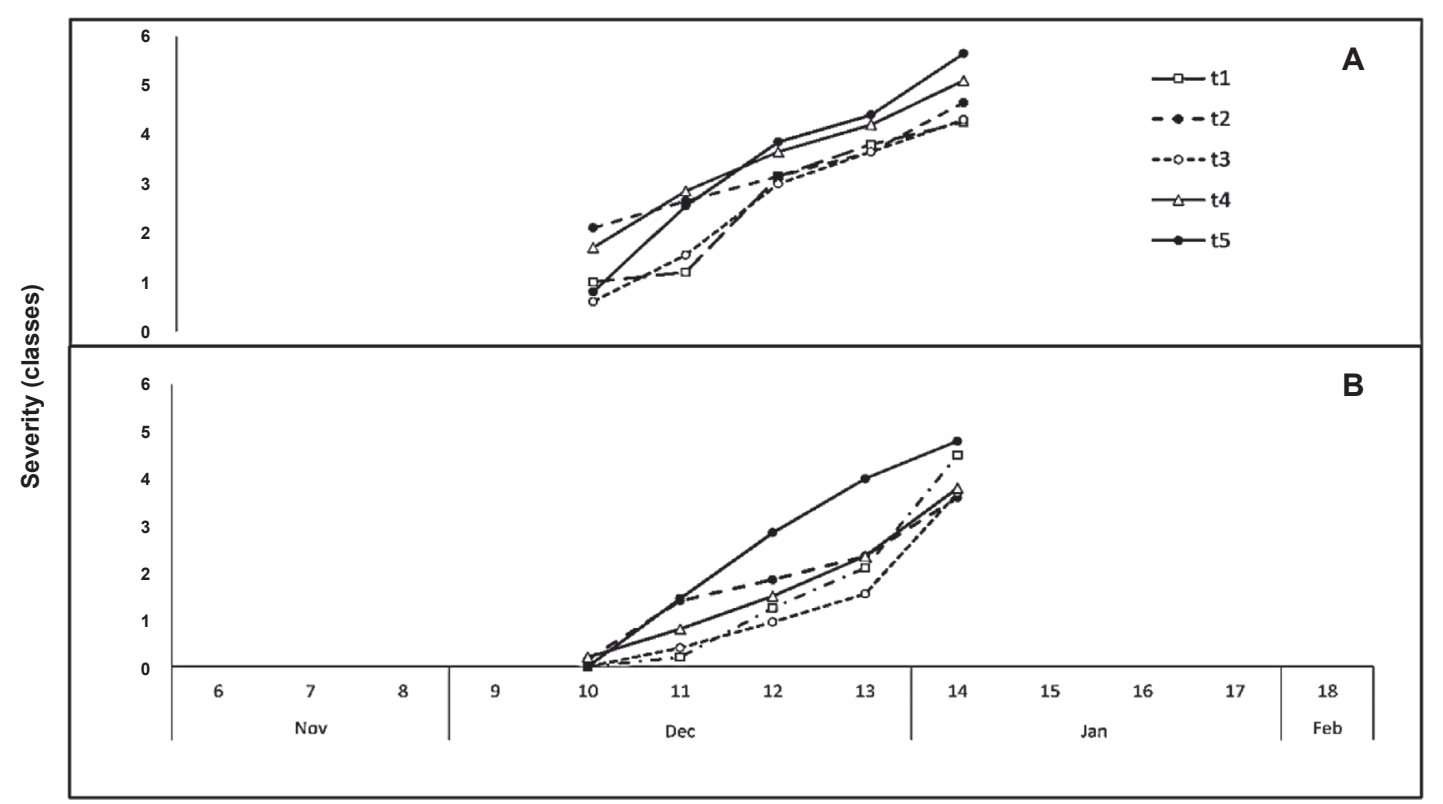

FIGURE 2 Colletotrichum gloeosporioides temporal progress curves on flowers (A) and vegetative shoots (B) of mango (Mangifera indica) during one floral flushing in five treatments in the commercial orchard "Zozontla 1", Arcelia, Guerrero.cv. Haden. Productive cycle 2010-2011.

$\mathrm{z}=$ Estimation of severity ranges by software Dos log for Windows $^{\circledR}$

TABLE 3 - Effect of treatments on parameters of the temporal progress of anthracnose (Colletotrichum gloeosporioides) epidemics on mango (Mangifera indica) inflorescence in the commercial orchards "Las Tunas", Tecpan de Galeana, cv. Manila and "Zozontla 1", Arcelia, cv. Haden, Guerrero. Productive cycle2010-2011

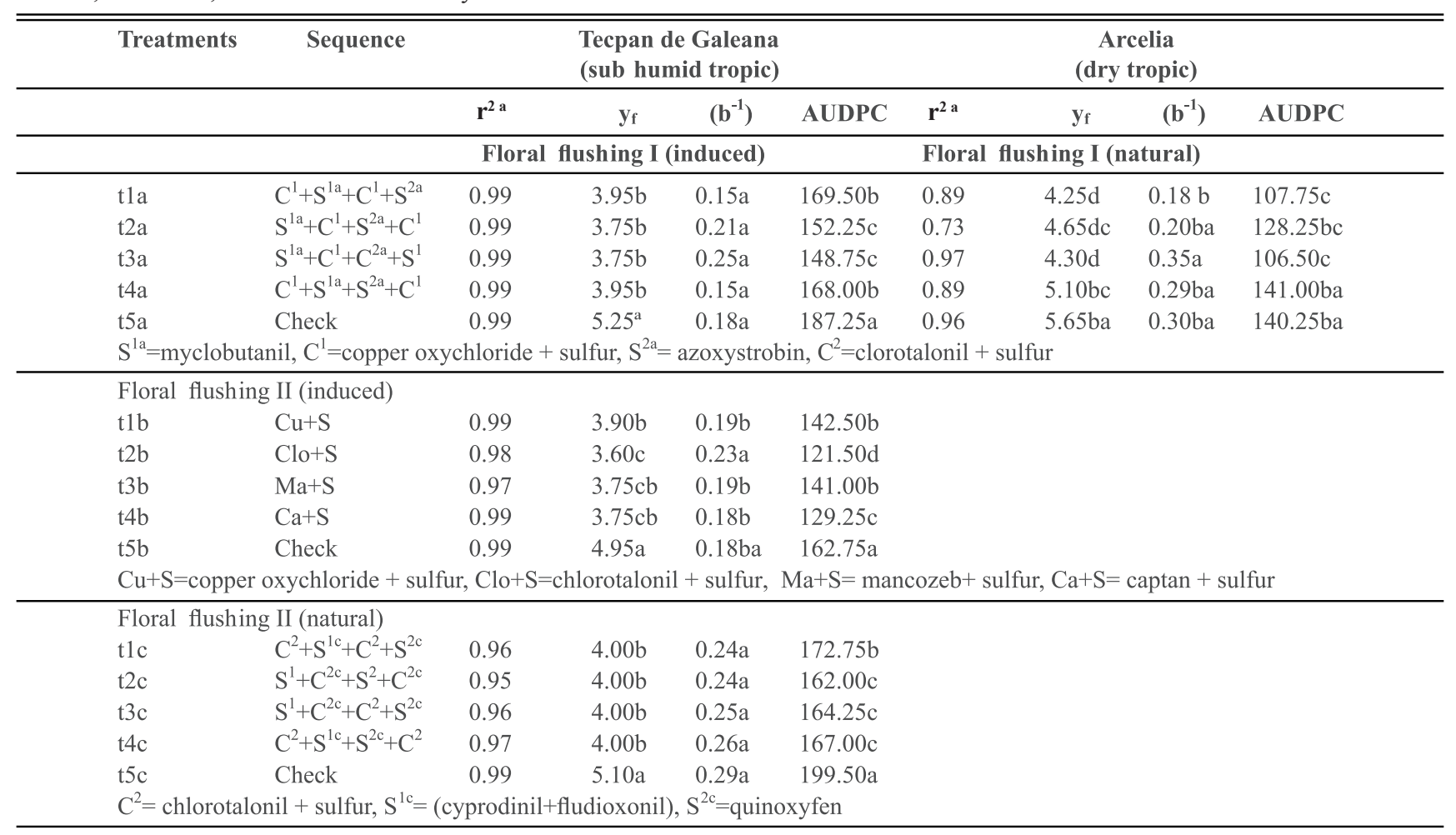

${ }^{a} \mathrm{r}^{2}=$ determination coefficient of the Weibull model, $\mathrm{y}_{\mathrm{f}}=$ final incidence, AUDPC $=$ area under disease progress curve, $\mathrm{b}^{-1}=$ increase ratio of the disease.

* Values with the same letter are not statistically different 
TABLE 4 - Effect of the treatments on parameters of the temporal progress of the anthracnose (Colletotrichum gloeosporioides) epidemics in mango (Mangifera indica) vegetative shoots in the commercial orchards "Las Tunas", Tecpan de Galeana, cv Manila and "Zozontla 1", Arcelia, cv. Haden, Guerrero. Productive cycle 2010-2011

\begin{tabular}{|c|c|c|c|c|c|c|c|c|c|}
\hline \multirow[t]{2}{*}{ Treatments } & \multirow[t]{2}{*}{ Sequence } & \multicolumn{4}{|c|}{$\begin{array}{l}\text { Tecpan de Galeana } \\
\text { ( sub-humid tropic) }\end{array}$} & \multicolumn{4}{|c|}{$\begin{array}{c}\text { Arcelia } \\
\text { (dry tropic) }\end{array}$} \\
\hline & & $\mathbf{r}^{2 \mathrm{a}}$ & $\mathbf{y}_{\mathbf{f}}$ & $\left(b^{-1}\right)$ & AUDPC & $\mathbf{r}^{2 \mathrm{a}}$ & $y_{f}$ & $\left(b^{-1}\right)$ & AUDPC \\
\hline & \multicolumn{5}{|c|}{ Floral flushing I (induced) } & \multicolumn{3}{|c|}{ Floral flushing I (induced) } & \\
\hline t1a & $\mathrm{C}^{1 \mathrm{a}}+\mathrm{S}^{1 \mathrm{a}}+\mathrm{C}^{1 \mathrm{a}}+\mathrm{S}^{2 \mathrm{a}}$ & 0.95 & $3.5 \mathrm{a}$ & $0.07 \mathrm{a}$ & $1.45 b$ & 0.95 & $4.50 \mathrm{a}$ & $58.00 \mathrm{~b}$ & $0.76 \mathrm{ba}$ \\
\hline $\mathrm{t} 2 \mathrm{a}$ & $\mathrm{S}^{1 \mathrm{a}}+\mathrm{C}^{1}+\mathrm{S}^{2 \mathrm{a}}+\mathrm{C}^{1}$ & 0.92 & $3.85 \mathrm{a}$ & $0.24 \mathrm{a}$ & $1.35 \mathrm{ba}$ & 0.92 & $3.60 \mathrm{~b}$ & $74.75 \mathrm{~b}$ & $0.39 \mathrm{ba}$ \\
\hline $\mathrm{t} 3 \mathrm{a}$ & $\mathrm{S}^{1 \mathrm{a}}+\mathrm{C}^{1}+\mathrm{C}^{2 \mathrm{a}}+\mathrm{S}^{1}$ & 0.90 & $3.65 \mathrm{a}$ & $0.06 \mathrm{a}$ & $1.15 b$ & 0.93 & $3.70 \mathrm{~b}$ & $47.50 \mathrm{~b}$ & $0.10 \mathrm{a}$ \\
\hline $\mathrm{t} 4 \mathrm{a}$ & $\mathrm{C}^{1}+\mathrm{S}^{1 \mathrm{a}}+\mathrm{S}^{2 \mathrm{a}}+\mathrm{C}^{1}$ & 0.98 & $3.75 \mathrm{a}$ & $0.09 \mathrm{a}$ & $1.50 \mathrm{ba}$ & 0.94 & $3.80 \mathrm{~b}$ & $66.50 \mathrm{~b}$ & $0.71 \mathrm{ba}$ \\
\hline & Check & 0.94 & $3.5 \mathrm{a}$ & $0.06 \mathrm{a}$ & $1.65 \mathrm{a}$ & 0.99 & $4.80 \mathrm{a}$ & $107.00 \mathrm{a}$ & $0.40 \mathrm{ba}$ \\
\hline \multicolumn{10}{|c|}{$\mathrm{S}^{1 \mathrm{a}}=$ myclobutanil, $\mathrm{C}^{1}=$ copper oxychloride + sulfur, $\mathrm{S}^{2 \mathrm{a}}=$ azoxystrobin, $\mathrm{C}^{2}=$ clorotalonil + sulfur } \\
\hline \multicolumn{10}{|c|}{ Floral flushing II (induced) } \\
\hline $\mathrm{tlb}$ & $\mathrm{Cu}+\mathrm{S}$ & 0.91 & $1.85 \mathrm{bc}$ & $0.11 \mathrm{~b}$ & $0.10 \mathrm{~b}$ & & & & \\
\hline $\mathrm{t} 2 \mathrm{~b}$ & $\mathrm{Clo}+\mathrm{S}$ & 0.97 & $2.40 \mathrm{ba}$ & $0.25 \mathrm{a}$ & $0.00 \mathrm{~b}$ & & & & \\
\hline $\mathrm{t} 3 \mathrm{~b}$ & $\mathrm{Ma}+\mathrm{S}$ & 0.90 & $2.25 \mathrm{ba}$ & $0.15 b$ & $0.00 \mathrm{~b}$ & & & & \\
\hline $\mathrm{t} 4 \mathrm{~b}$ & $\mathrm{Ca}+\mathrm{S}$ & 0.97 & $1.55 \mathrm{c}$ & $0.12 b$ & $0.00 \mathrm{~b}$ & & & & \\
\hline $\mathrm{t} 5 \mathrm{~b}$ & Check & 0.92 & $2.75 \mathrm{a}$ & $0.14 \mathrm{~b}$ & $0.35 \mathrm{a}$ & & & & \\
\hline \multicolumn{10}{|c|}{$\mathrm{Cu}+\mathrm{S}=$ copper oxychloride + sulfur, $\mathrm{Clo}+\mathrm{S}=$ chlorotalonil + sulfur, $\mathrm{Ma}+\mathrm{S}=$ mancozeb + sulfur, $\mathrm{Ca}+\mathrm{S}=$ captan + sulfur } \\
\hline \multicolumn{10}{|c|}{ Floral flushing III (natural) } \\
\hline $\mathrm{t} 1 \mathrm{c}$ & $\mathrm{C}^{2 \mathrm{c}}+\mathrm{S}^{1 \mathrm{c}}+\mathrm{C}^{2 \mathrm{c}}+\mathrm{S}^{2 \mathrm{c}}$ & 0.96 & $2.35 \mathrm{ba}$ & $0.08 \mathrm{a}$ & $0.0 \mathrm{~b}$ & & & & \\
\hline $\mathrm{t} 2 \mathrm{c}$ & $\mathrm{S}^{1 \mathrm{c}}+\mathrm{C}^{2 \mathrm{c}}+\mathrm{S}^{2 \mathrm{c}}+\mathrm{C}^{2 \mathrm{c}}$ & 0.98 & $2.25 \mathrm{~b}$ & $0.09 \mathrm{a}$ & $0.0 \mathrm{~b}$ & & & & \\
\hline$t 3 c$ & $\mathrm{~S}^{1 \mathrm{c}}+\mathrm{C}^{2 \mathrm{c}}+\mathrm{C}^{2 \mathrm{c}}+\mathrm{S}^{2 \mathrm{c}}$ & 0.96 & $1.85 \mathrm{~b}$ & $0.09 \mathrm{a}$ & $0.0 \mathrm{~b}$ & & & & \\
\hline $\mathrm{t} 4 \mathrm{c}$ & $\mathrm{C}^{2 \mathrm{c}}+\mathrm{S}^{1 \mathrm{c}}+\mathrm{S}^{2 \mathrm{c}}+\mathrm{C}^{2 \mathrm{c}}$ & 0.91 & $2.20 \mathrm{~b}$ & $0.09 \mathrm{a}$ & $0.0 \mathrm{~b}$ & & & & \\
\hline & Check & 0.90 & $3.10 \mathrm{a}$ & $0.09 \mathrm{a}$ & $0.2 \mathrm{a}$ & & & & \\
\hline \multicolumn{10}{|c|}{$\mathrm{C}^{2}=$ chlorotalonil + sulfur, $\mathrm{S}^{1 \mathrm{c}}=($ cyprodinil + fludioxonil $), \mathrm{S}^{2 \mathrm{c}}=$ quinoxyfen } \\
\hline
\end{tabular}

epidemics. For example, in Tecpan de Galeana (subhumid tropic), temperatures $<20^{\circ} \mathrm{C}$ were recorded more frequently and with greater persistence (h/week) between January and March 2010 (winter) and caused up to three growth flushing which promoted a most number of epidemics (30 severity curves; 15 floral and 15 vegetative) (Figure 1).

Contrastingly, in Arcelia (where there is a uniform winter season) there was only one growth flushing and 10 epidemics (five floral and five vegetative) (Figure 2). Moreover, the timely and efficient application of management practices as floral flushing inducers $\left(\mathrm{KNO}_{3}\right.$, $3 \%$ ) will also influence phenology: inadequate applications of this growth promoter will affect the ratio of vegetative and floral shoots in each growth flushing (Yeshitela et al., 2004), and therefore the intensity of the epidemics per tissue mode. For this reason, in places where there is more than one stage of epidemics (more than one vegetative or floral flushing) per reproductive or agronomical stage a greater use of systemic fungicides is needed, and it will be indispensable to diversify applications using different combinations and sequences of systemic and contact fungicide applications to reduce the risk of resistance as suggested by Muiño et al. (2007) and Sampath et al. (2007).
Anthracnose control in Mexico is mainly based on the use of benzimidazole fungicides, however, in these products it is reported many cases of resistance (Gutierrez et al., 2003; Hsin, 2009; Vega, 1994). The best results in this study were obtained with myclobutanil, azoxystrobin, quinoxyfen and cyprodynil+fludioxonil as documented Gengotti et al. (2008), Nieto et al. (2003), Sundravadana et al. (2009), Tsai et al. (2006) and Wong \& Midland (2007). Moreover, these products are authorized for use with mango in Mexico (MRL, 2010; SAGARPA, 2010).

The best control in Guerrero was obtained by starting with a prophylactic spray of a systemic fungicide alternated with chlorotalonil + sulfur (Acosta et al., 2003). The rotation of active ingredients and timely application must be based on the presence of susceptible phenology stages, regardless the number of floral growths. It must be consider that to improve chemical management, it should be combined with crop practices that decrease environmental humidity in the orchard, such as ventilation pruning, avoiding excessive irrigation, improving drainage, timely weed control and destroy sources of the inoculum (Acosta et al., 2003; Arauz, 2000). 


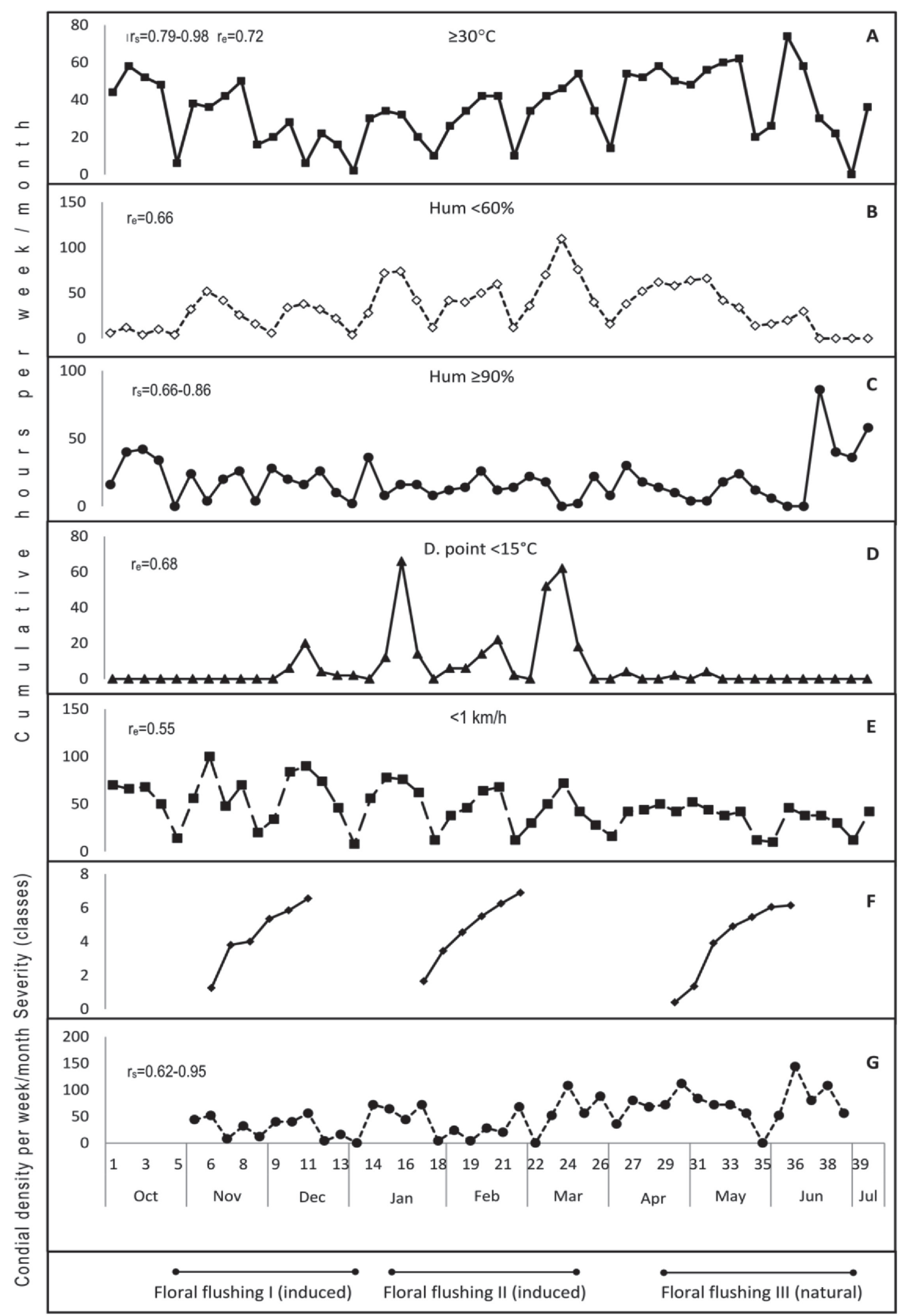

FIGURE 3 - Colletotrichum gloeosporioides conidial density (G), anthracnose severity in inflorescence (F) and relationship with temperature (A), relative humidity (B and C), dew point (D) and wind speed (E), during three floral flushings in the commercial mango (Mangifera indica) orchard "Las Tunas", Tecpan de Galeana, Guerrero. cv. Manila. Productive cycle 2010-2011. $\mathrm{r}_{\mathrm{s}}=$ correlation coefficient (Pearson) with severity, $\mathrm{r}_{\mathrm{e}}=$ correlation coefficient (Pearson) with conidial density. 


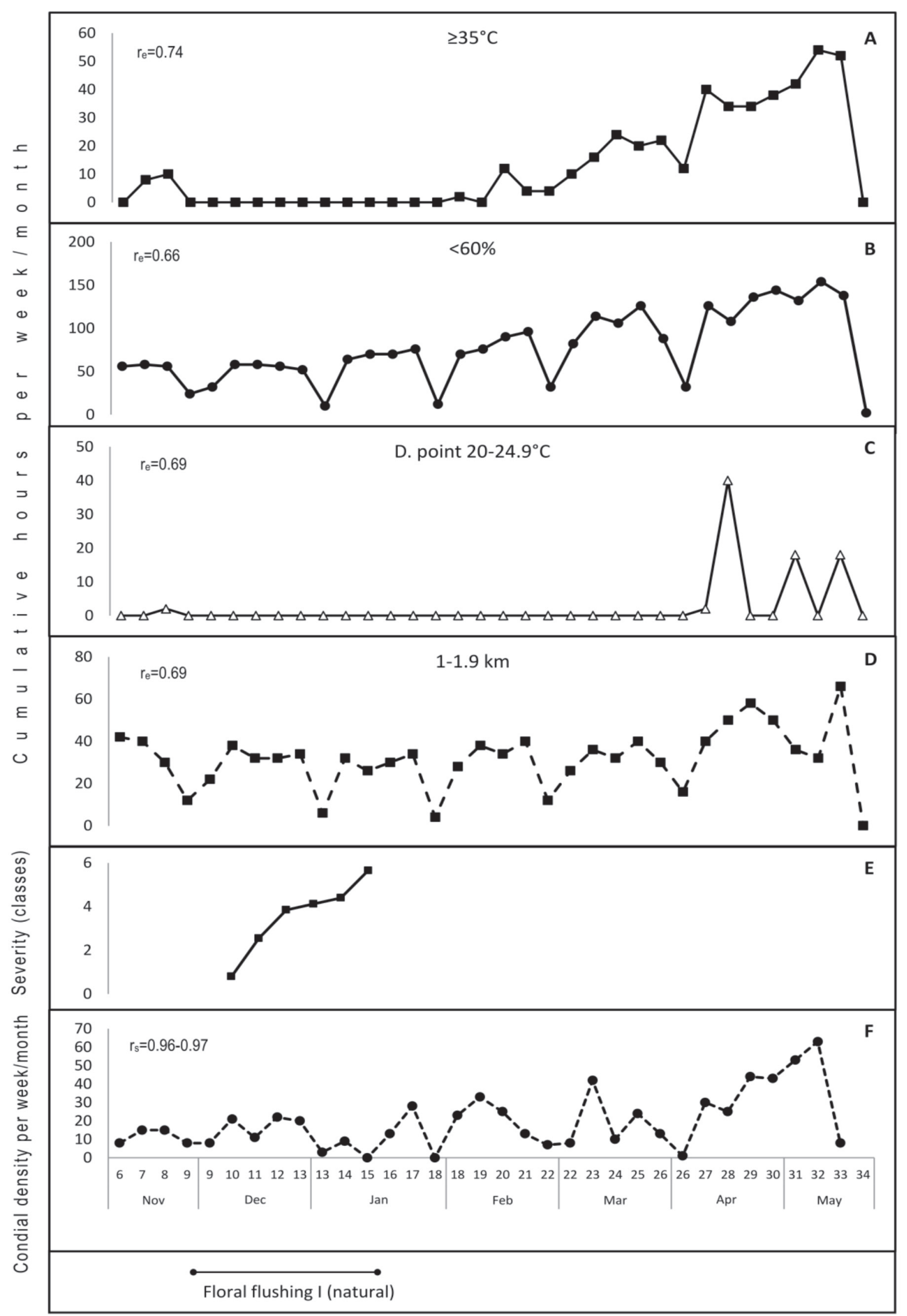

FIGURE 4 - Colletotrichum gloeosporioides conidial density (F), anthracnose severity in inflorescence (E) and relationship with temperature (A), relative humidity (B), dew point (C) and wind speed (D), during one floral flushing in the commercial mango (Mangifera indica) orchard "Zozontla 1", Arcelia, Guerrero. cv. Haden. Productive cycle 2010-2011.

$\mathrm{r}_{\mathrm{s}}=$ correlation coefficient (Pearson) with severity, $\mathrm{r}_{\mathrm{e}}=$ correlation coefficient (Pearson) with conidial density. 
In this study, the best results were obtained when beginning applications with a systemic ingredient followed by a contact fungicide, as suggested Rivas \& Carrizales (2007) in Venezuela. However, given the scarcity of studies that include such approach, it is suggested that further studies will be critical to adjust the efficiency of strategy. It is important to point out that in our study, the climatic conditions and inoculum availability do not constitute limiting factors during the emission periods of susceptible tissue in either study zone. Therefore, is obliged a preventive and more prolonged control of the disease. It also justifies prophylactic sprayings of fungicides of different chemical groups, mode of action, and application sequence.

Our data shows that sporulation and severity were correlated with temperature $\geq 30^{\circ} \mathrm{C}$. This is a determinant in the mango-anthracnose system. It was observed that the inoculum was available during the whole study period in both regions (Figures 3 and 4), so that the severity of anthracnose epidemics will depend on susceptible tissue and favorable environment. In general, temperature and humidity in sub-humid $\left(\geq 30^{\circ} \mathrm{C}\right.$ and $\left.\geq 90 \% \mathrm{RH}\right)$ and $\operatorname{dry}\left(\geq 35^{\circ} \mathrm{C}\right.$ y $\left.<60 \% \mathrm{RH}\right)$ tropics were adequate for the disease development (Estrada et al., 2000), the sporulation is a constant pressure factor during the winter-spring growth flushing in Mexico. These results were similar to those reported by Holguin et al. (2009), who documented that the severity in vegetative growths coincided with humidity levels of $80-90 \%$ and dew point (22$26^{\circ} \mathrm{C}$ ) and partially coincided with Acosta (2002), who documented that the severity of anthracnose depended on conidial density, incidence and rainfall. In Michoacan, conidial density was positively related with severity and epidemics were adequately described by the Weibull model (Guillén, 2000). Estrada et al. (2000) in Philippines and Sangeetha \& Rawal (2009) in India documented that temperature of $25-30^{\circ} \mathrm{C}$ and humidity $\geq 90 \%$ favor fungal sporulation. Due to the fact that our study was done in the dry season, correlation of severity and conidial density to precipitation could not be calculated. However, this factor is essential and must be included in future studies. Nevertheless, this research makes evident the capability of $C$. gloeosporioides to cause infections in the flowering stage with such low humidity $(<60 \%)$ as that reported in the dry tropic.

\section{REFERENCES}

Acosta RM (2002) La antracnosis (Colletotrichum gloeosporioides Penz.) del mango (Mangifera indica L.) cv. Haden: Patogenicidad, control químico, manejo y epidemiología. Tesis Doctoral, Colegio de Postgraduados, Instituto de Fitosanidad. Montecillo, Estado de México.
Acosta MR, Noriega DH, Nieto DA, Téliz DO (2003) Efecto del manejo integrado del mango (Mangifera indica L.) en la incidencia de enfermedades y en la calidad de frutos. Revista Mexicana de Fitopatología 21:46-55.

Arauz LF (2000) Mango anthracnose: Economic impact and current options for integrated management. Plant Disease 84:600611.

Benítez FA, Huerta PG, Holguín FM, Toledo JA (2003) Efecto de Colletotrichum gloeosporioides (Penz.) Penz. and Sacc. en la caída de frutos de mango cv. Ataulfo en el Soconusco, Chiapas, México. Revista Mexicana de Fitopatología 21:223-227.

Campbell CL, Madden LV (1990) Introduction to Plant Disease Epidemiology. New York NY. John Wiley \& Sons Inc.

Estrada AB, Dodd JC, Jeffries P (2000) Effect of humidity and temperature on conidial germination and appressorium development of two Philippine isolates of the mango anthracnose pathogen Colletotrichum gloeosporioides. Plant Pathology 49:608-618.

FAOSTAT (2010) Organización de las Naciones Unidas para la Alimentación y la Agricultura. Available at: http://faostat.fao.org/ DesktopDefault.aspx?PageID=339\&lang=es. Accessed on May 28, 2012.

FRAC (2006) Mode of action of fungicides. Available at: www. frac.info. Accessed on May 28, 2012.

Galán SV (1999) El Cultivo del Mango. $2^{\text {nd }}$ ed. Madrid Spain. Mundi-Prensa.

Gengotti S, Ceredi G, Antoniacci L, Paoli E, Montuschi C (2008) Evaluation of some fungicides against anthracnose (Colletotrichum acutatum) on open field strawberry. Giornate Fitopatologiche 2:407-412.

Guillén SD (2000) Epidemiología de Cenicilla (Oidium mangiferae Berthet.) y Antracnosis (Colletotrichum gloeosporioides Penz) del Mango en Michoacán. Tesis de Maestría, Colegio de Postgraduados, Instituto de Fitosanidad. Montecillo, Estado de México.

Gutiérrez O, Gutiérrez JG, Nieto DA, Teliz DO, Zavaleta EM, Delgadillo FS, Vaquera HH (2003) Evaluación de resistencia a benomil, thiabendazol y azoxystrobin para el control de antracnosis (Colletotrichum gloeosporioides Penz.) en frutos de guayaba (Psidium guajava L.) en postcosecha. Revista Mexicana de Fitopatología 21:228-232.

Holguín MF, Huerta PG, Benítez CF, Toledo AJ (2009) Epidemiología de la antracnosis Colletotrichum gloeosporioides (Penz.) Penz. And Sacc. en mango (Mangifera indica L.) cv. Ataulfo en el Soconusco, Chiapas, México. Revista Mexicana de Fitopatología 27:93-105.

Hsin CW, Chuan CW, Tsu PM, Ren YH, Wen HJ (2009) Specific detection of benzimidazole resistance in Colletotrichum gloeosporioides from fruit crops by PCR-RFLP. Biocatalysis and Agricultural Biotechnology 3:17-24.

Jeffries P, Dodd JC, Jeger MJ, Plumbley RA (1990) The biology and control of Colletotrichum species on tropical fruit crops. Plant Pathology 39:343-366.

Mora AA, Téliz OD (2002) Enfermedades del mango. In. Mora AA, Téliz OD, Rebouças SJA (Eds.) Mango: Manejo y Comercialización. Colegio de Postgraduados en Ciencias Agrícolas. México. pp. 55-171. 
Mora AA, Téliz DO, Mora AG, Sánchez PG, Mercado JJ (2003) Progreso temporal de escoba de bruja (Fusarium oxysporum y F. subglutinans) en huertos de mango (Mangifera indica L.) cv. Haden en Michoacán, México. Revista Mexicana de Fitopatología 21:1-12.

MRL 2010. Maximum Residue Limit Database. Available at: http://www.fas.usda.gov/htp/mrl.asp. Accessed on May 28, 2012.

Muiño BL, Pérez L, Pollanco AA, Ponciano I, Lorenzo ME, Martín EL, González MV, Arébalo RA, Rodríguez JN, Albelo MT, Santana Y (2007) El monitoreo y manejo de la resistencia a los fungicidas en Cuba. Fitosanidad 11:91-100.

Nieto DA, Gutiérrez JG, Gutiérrez O, Teliz DO, Zavaleta E, Delgadillo F, Vaquera H(2003) Evaluación de resistencia a imazalil, prochloraz y azoxystrobin en aislamientos de [Colletotrichum gloeosporioides (Penz.) Penz. and Sacc.] y control de la antracnosis del mango. Revista Mexicana de Fitopatología 21:379-383.

Osuna ET, Engleman EM, Becerril RE, Mosqueda VR, Soto HM, Castillo MA (2000) Iniciación y diferenciación foral en mango "Manila". Agrociencia 34:573-581.

Pennypecker SP, Knodle HD, Antle CD, Madden LV (1980) A flexible model for studying plant disease progression. Phythopathology 70:232-235.

Rivas BA, Carrizales L (2007) Control químico de la antracnosis del mango (Mangifera indica L.) en pre y postcosecha en el municipio Cedeño, estado Monagas, Venezuela. Bioagro 19:19-25.

SIAP 2010. Servicio de información agroalimentaria y pesquera. Available at: www.siap.gob.mx/index. www.siap.gob.mx/index. Accessed on May 28, 2012.

Sampath AK, Eswara NR, Hariprasad KR, Charitha MD (2007) Evaluation of fungicidal resistance among Colletotrichum gloeosporioides isolates causing mango anthracnose in Agri Export Zone of Andhra Pradesh, India. Plant Pathology Bulletin 6:157-160.
SAGARPA 2010. Secretaria de Agricultura, Ganaderia, Desarrollo rural, Pesca y Alimentacion. Available at: http://www.senasica. gob.mx/?doc=22993. Accessed on July 11, 2010.

Sangeetha CG, Rawal RD (2009) Temperature requirement of different isolates of Colletotrichum gloeosporioides isolated from Mango. American-Eurasian Journal of Scientific Research 41:2025 .

SMN 1971-2012. Sistema Meteorológico Nacional. Available at: www.siap.gob.mx/index www.siap.gob.mx/index Accessed on May 28, 2012.

Sundravadana S, Alice D, Kuttalam S, Samiyappan R (2009) Efficacy of azoxystrobin on Colletotrichum gloeosporioides Penz. growth and on controlling mango anthracnose. Journal of Agricultural and Biological Science 2:10-15.

Tsai JN, Ann PJ, Hu CY, Cheng SF (2006) Evaluation of fungicides for suppression of mycelial growth and conidial germination of Colletotrichum species isolated from mango, pomelo and banana fruit. Plant Pathology Bulletin 15:39-54.

Vega, PA (1994) Enfermedades del mango (Mangifera indica L.) en el valle de Apatzingán. SARH-INIFAP 26.

White DH, Lubulwa G, Menz K, Zuo H, Wint W, Slingenbergh J (2001) Agroclimatic classifcation systems for estimating the global distribution of livestock numbers commodities. Environment International 27:181-187.

Wong FP, Midland SL (2007) Sensitivity distributions of California populations of Colletotrichum cereale to the DMI fungicides propiconazole, myclobutanil, tebuconazole, and triadimefon. Plant Disease 91:1547-1555.

Yeshitela T, Robbertse PJ, Stassen PJ (2004) Potassium nitrate and urea sprays affect flowering and yields of 'Tommy Atkins' (Mangifera indica) mango in Ethiopia. New Zealand Journal of Crop \& Horticultural Science 32:209-215.

TPP 2012-0039 - Received 20 June 2012 - Accepted 23 August 2012 Section Editor: Emerson M. Del Ponte 